\title{
Does organizational commitment mediate the impact of organizational culture and interpersonal
} communication on organizational citizenship behavior?

\author{
Dewi Susita $^{a^{*}}$, I. Ketut R. Sudiarditha ${ }^{a}$, Dedi Purwana ${ }^{a}$, Christian Wiradendi Wolor ${ }^{a}$ and Restia \\ Merdyantie $^{\mathrm{a}}$
}

${ }^{a}$ Faculty of Economics, Universitas Negeri Jakarta, Indonesia

CHRON I C L E A B S T R A C T

\begin{tabular}{l} 
Article history: \\
Received: February 16, 2020 \\
Received in revised format: \\
March 272020 \\
Accepted: March 29, 2020 \\
Available online: \\
April 1, 2020 \\
\hline Keywords: \\
Organizational culture \\
Interpersonal communication \\
Organizational commitment \\
Organizational citizenship behav- \\
ior
\end{tabular}

\section{Introduction}

Development of the tourism sector concerns on socio-cultural, economic and political aspects (Adianita et al., 2017). This is in line with what is stated in Law Number 10 of 2009, about the implementation of tourism is aimed at increasing national income in order to improve people's welfare and prosperity, expand and equalize business and employment opportunities, encourage regional development, introduce and utilize objects and power tourist attraction in Indonesia and improve a sense of love for the country and strengthen friendship between nations. The tourism industry in Indonesia is noted to be the important factor of national economic development and a savior of foreign exchange. Through Wonderful Indonesia's branding, Indonesia's tourism competitiveness ranking in the world continues to rise. The Indonesia tourism ranking was increased from ranking 70 in 2013 to ranking 50 in 2015, Indonesia's competitiveness index shot back up 8 places to rank 42 in 2017 (World Economic Forum, 2017). It is estimated that almost 9\% of the total national workforce is employed in the tourism sector. At present, the Indonesian tourism sector accounts for 4\% of the total economy (Indonesia Investment, 2018). The industry of hospitality is the biggest part of the world of tourism. One of the companies engaged in the hospitality industry in Jakarta is PT. Jaktour. Based on the pre-survey research result, it was found that some employees still did not show the

* Corresponding author

E-mail address: dewisusita_man@unj.ac.id (D. Susita)

(C) 2020 by the authors; licensee Growing Science, Canada doi: $10.5267 /$ j.msl.2020.4.004 
OCB behavior, including not being willing to help coworkers who were having difficulty doing their jobs, not doing work outside of their job descriptions, not cooperating with fellow colleagues, there were still conflicts between fellow employees and superiors and less actively participate in the activities held by the company. Some research results, including Banhwa et al. (2014), found that OCB was influenced by Organizational Employees and Engagement Strategies. According to Zanuchi et al. (2014) and Badawy et al., (2016), OCB is influenced by organizational culture and job satisfaction. Likewise Kasraie Sh et al. (2014), there is a significant positive relationship between work life quality, job stress, job satisfaction, and citizenship behavior. On the other hand, Khan et al. (2015) research found that OCB was influenced by organizational culture and organizational commitment. Whereas Anam and Chairul (2017), found that interpersonal communication had an effect on the formation of OCB. Various studies have been conducted regarding OCB using 3 (three) indicators from Podsakoff et al. (2000). OCB is: Helping behavior, which is mutual helping behavior among others and prevents laziness in work. Civic virtue, concerns the support of workers for administrative functions in the organization. Sportsmanship, describes workers who place more emphasis on looking at positive aspects than negative aspects of the organization. But this research uses 5 indicators, namely altruism, Conscientiousness, Sportmanship and Courtessy, and Civic Virtue, which will make the model put interpersonal communication as independent. The contribution to the science of human resource management is the discovery that in addition to the organizational culture it is seen the importance of interpersonal communication and organizational commitment in increasing employee OCB. This study aims to see the influence of organizational culture, interpersonal communication, on OCB with commitment as mediation (Organ, 2015).

\section{Literature Review}

\subsection{Organizational Citizenship Behavior $(O C B)$}

According to Organ et al., (2008), OCB is a form of behavior that is an individual choice and initiative. while Deery et al. (2016) state that OCB is an individual contribution that causes higher performance, this is supported by Mahasneh's opinion (2015), who argues that OCB is a behavior that benefits the organization and / or tends to benefit the organization, voluntarily and beyond what the role demands. OCB according to Organ (2015), consisting of Altruism, Conscientiousness, Sportmanship and Courtessy, and Civic Virtue. While according to Podsakoff et al., (2000), OCB is: Helping behavior, which is mutual helping behavior among others and prevents laziness in work. Civic virtue, concerns the support of workers for administrative functions in the organization. And Sportsmanship, describes workers who place more emphasis on looking at positive aspects than negative aspects of the organization. Sportsmanship describes the sportsmanship of a worker towards the organization. OCB measuring instrument compiled by Lee and Allen (2002), namely: OCB-I (organizational citizenship behavior towards individuals), OCB-O (organizational citizenship behavior towards organization) is OCB that is carried out by an employee aimed at the organization as a whole, also profitable organization in general. Based on the explanation, it can be synthesized that $\mathrm{OCB}$ is an organizational behavior in the voluntary form of employees to do extra work which includes altruism, conscientiousness, sportmanship, courtessy and civic virtue.

\subsection{Organizational Commitment}

Luthans and Fred (2011) defined organizational commitment as: (1) a strong desire to remain as a member of a particular organization, (2) a desire to urge effort at a high level, and (3) definite confidence in and acceptance of values and aim, organization and its continued success and well-being. While Schermerhorn et al. (2011), defines organizational commitment as someone's loyalty to the organization. Another opinion of organizational commitment is the desire of someone to continue working in his organization (Colquitt et al., 2019) and a definite desire to maintain organizational membership. While Newstrom (2008), organizational commitment is the level of a person's sharedness with the organization and its desire to continue to actively participate in it. Robbins and Judge (2015) represent the organization's commitment to bind and maintain the organization. Organizational commitment is reflected in three general components; namely affective commitment, continuance commitment, and normative commitment. Employees with strong affective commitments will remain with the organization in this case the company because they want it, employees with strong continuance commitments because they need it, while employees with strong normative commitments because they feel they have a big responsibility to the company. According to Moohead and Griffin (2013), organizational commitment reflects the identification and bond of an individual in the organization. According to Kreitner and Kinicki (2014), organizational commitment reflects the degree to which a person recognizes an organization and is bound to its goals. Commitment influences OCB, which is supported by the opinion of Sharma and Dhar (2016); Subejo et al., (2013), and Khan et al. (2015). In the opinion of some experts it can be concluded that organizational commitment is an attitude of confidence shown by employees towards their organization in this case the company, where he feels that he has fused with all values related to the company, has high loyalty, and is willing to strive for achieving goals company. with indicators of affective commitment, continuance commitment, normative commitment. According to Near and Jansen in Sopiah (2008); Robbin and Judge (2015) the impact arising from organizational commitment is behavior as a member of a higher organization (higher organizational citizenship behavior). While Luthans and Fred (2011) state that employee commitment is related to other desired outcomes such as perception, climate, and a team that is warm and supportive of the organization. The state is supported by Putrana et al. (2016); Purnami (2013) and Maysarah et al., (2015). Felicia (2017) analyzes the influence of organizational culture, organizational justice and organizational commitment to OCB. 


\section{Organizational Culture}

Organizational culture is a set of assumptions that are implicitly divided and accepted and held by a group that determines how it is perceived, thought and reacts to a diverse environment. According to Kreitner and Kinicki (2014), and Robbins and Koulter (2016), organizational culture is a set of values, principles, traditions, and ways of working that are shared by and influence the behavior and actions of members of the organization. Opinion of Robbins and Judge (2015), organizational culture can distinguish an organization from other organizations. Organizational culture is the norms and values that direct the behavior of organizational members (Likewise et al., 2011). While according to Mondy \& Noe (2012), organizational culture is a system of shared values, beliefs and habits in an organization that interacts with its formal structure to obtain behavioral norms. The organization needs to pay attention to its organizational culture, the reason being (Kreitner \& Kinicki, 2014): (1) Give members the organizational identity (2) Facilitate collective commitment (3) Promote social system stability (4) Shape behavior by helping members make sense of their surroundings. While the functions of organizational culture according to Noe and Mondy (2008) are: (1) Providing a sense of identity to the members of the organization to understand the vision, mission and become an integral part of the organization. (2) Produce and increase organizational commitment to the organization's mission. (3) Providing direction and strengthening behavioral standards to control organizational actors to carry out their duties and responsibilities effectively and efficiently to achieve agreed organizational goals and objectives. Organizational culture influences organizational commitment and employee performance (Usmany et al., 2016). Whereas Oemar \& Yohanes (2013); Dewi et al., (2017): Ariani et al., (2017), found that organizational culture influences organizational commitment and OCB. Rashid et al., (2003) also found a correlation between organizational culture and organizational commitment. Putra and Putra (2018) found that work culture influences organizational commitment and influences OCB. According to Sopiah (2008), organizational culture is closely related to employee commitment. Employee commitment is a behavioral dimension that can be used to assess the tendency of employees to survive as members of the organization. A good organizational culture will increase members' ownership and commitment to their organizations and work groups (Robbins and Judge, 2015). Sutrisno (2017) states that organizational culture is a guideline in achieving high organizational commitment. Furthermore, organizational culture facilitates the emergence of commitment rather than self-interest (Robbins $\&$ Koulter, 2016). Tika (2014) explains that the main function of organizational culture is as an adhesive for employees in an organization. This is part of the collective commitment of employees. They are proud of being an employee of an organization. Employees have a sense of belonging, participation and a sense of responsibility for the progress of their company. Mondy \& Noe (2005) explain that organizational culture functions to generate and increase commitment to the organization's mission. Kreitner and Kinicki (2014), explain that organizational culture facilitates collective commitment.

Culture functions as a mechanism for making meaning of controls that guides and shapes the attitudes and behavior of its members (Indrawijaya, 2010). According to Gordon in Sutrisno (2017); Robbins \& Judge (2015), in a strong culture, the noble values of the organization will be embraced intensively and widely disseminated. The members receive noble values and the greater their commitment, the stronger the culture and the greater the influence on members' behavior. Based on the explanation of organizational culture characteristics, it can be synthesized that organizational culture is the values, attitudes, and behavior of each member in an organization that reflects the organization and also distinguishes organizations from other organizations that are followed by all members of the organization with characteristics of innovation and courage to take risks, attention to detail, results-oriented, human-oriented, team-oriented, aggressive attitude and stability. The research conducted by Wijaya et al., (2017), aims to analyze the impact of organizational culture and organizational support on organizational citizen behavior (OCB) with organizational commitment as an intervening variable, as well as research Ariani et al., (2017), aiming to test the significance of the influence of organizational culture on affective commitment, the effect of affective commitment on OCB, the influence of organizational culture on OCB and the mediating effect of affective commitment on the influence of organizational culture on OCB. Likewise from the results of research conducted by Khan et al. (2015), discussing the influence of organizational commitment, organizational culture, leadership and organizational justice on OCB, shows that there is a significant positive relationship between organizational commitment, organizational culture, leadership, organizational justice against OCB. The results of research conducted by O'Reily, Chatman \& Caldwell and Sheridan (in Sutrisno, 2015) show the importance of organizational cultural values in influencing individual attitudes and attitudes. Likewise Mustikasari \& Anis (2014), aim to determine the effect of organizational culture on employee commitment. Besides Usmany et al., (2016); Dewi et al., also found an influence of organizational culture on organizational commitment.

\section{Interpersonal Communication}

Interpersonal communication according to Cangara (2010), is a process of communication that takes place between two or more people face to face. While Suranto (2011), interpreted as the process of delivering news, both in the direction and in two directions According to DeVito (2004), interpersonal communication is a verbal and non verbal interaction between two (or sometimes more than two) people who are interdependent. Thoha (2016) interpersonal communication is actually the same as the notion of communication that is well known in general.

Components - components of communication according to Suranto (2011), includes: source, encoding, message, channel, receiver / communicant, decoding, response, interference (noise) and communication context. The objectives of Interpersonal communication include: conveying information to others, sharing experiences with others, fostering sympathy, collaborating 
and generating motivation. The effectiveness of interpersonal communication starts with five general qualities that are considered namely openness, empathy, supportiveness, positiveness, equality (De Vito, 2004). From the description, it can be synthesized that interpersonal communication is a process of delivering and receiving messages between two people face to face directly accompanied by feedback with the characteristics of openness, empathy, supportiveness, positiveness, and equality. Internal communication affects commitment, this is supported by the opinions of Lindawati \& Rita (2014) and Winata (2017). Its relevan with opinion of Siburian \& Tiur (2013). While Herfina et al. (2015) explain that there is a relationship between interpersonal skills with OCB (2015). On the other hand Sopiah (2008); Young et al (in Sopiah 2008); Luthans \& Fred (2011), explain that organizational commitment can be increased by clarifying and communicating missions. Along with the results of the Siburian study (2013); Lindawati \& Rita (2014), found that interpersonal communication has a significant effect on organizational commitment. Interpersonal communication serves to build organizational commitment by making wider two-way communication to build charisma (Sopiah, 2008; Dessler, 2008). Luthans \& Fred (2011); Robbins \& Judge (2015), and Indrawijaya (2010), communication acts to control employee behavior. Anam (2017), found that there was an influence of organizational commitment, interpersonal communication and job satisfaction on OCB. Winata (2017) found there was a direct influence of managerial skills, interpersonal communication and quality culture on the behavior of organizational members (OCB) on public elementary school teachers. Herfina et al., (2015), getting the results of the study showed that interpersonal communication had an effected on OCB.

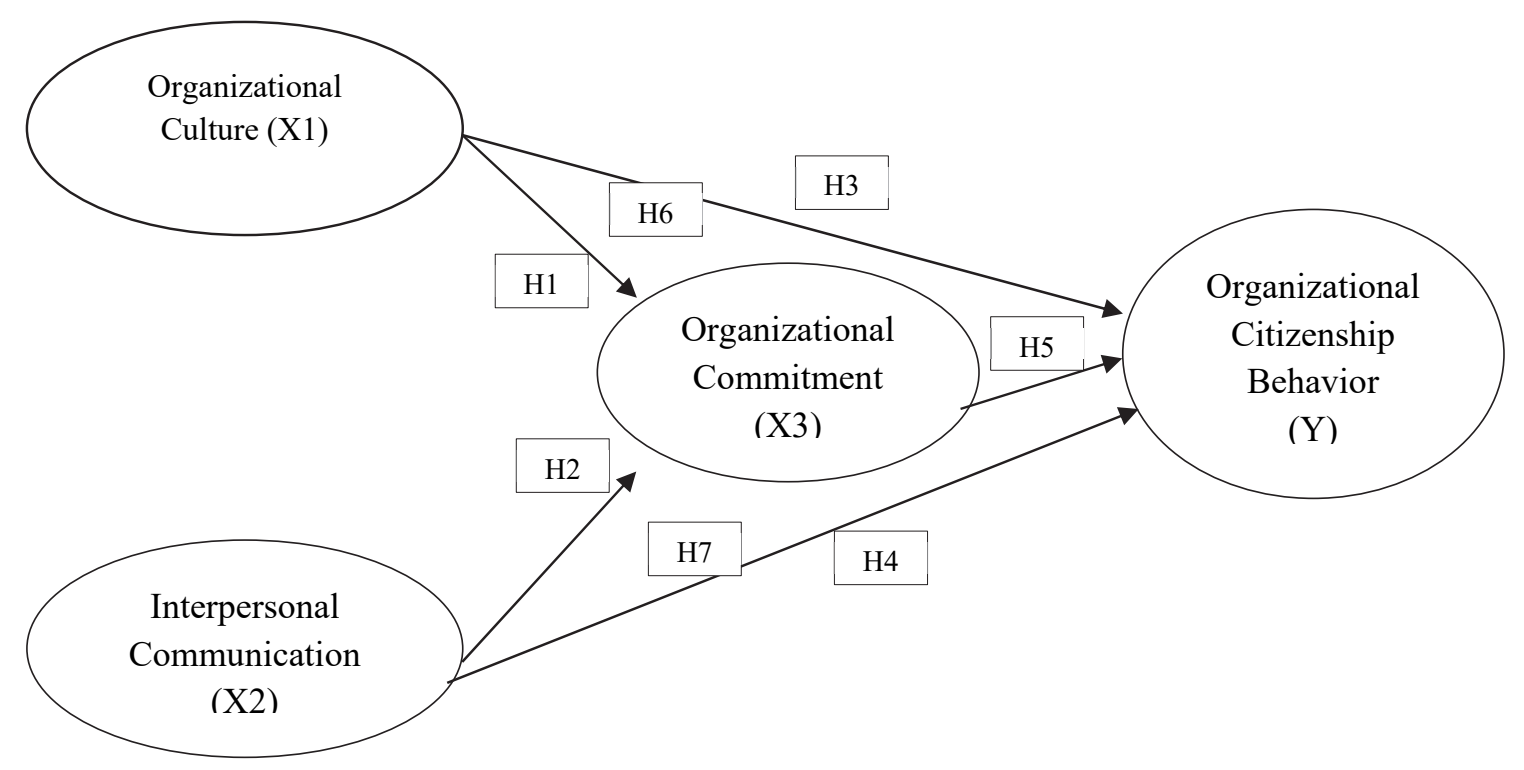

Fig. 1. Research Framework

The Research Hypotheses:

H1: Organizational culture influences organizational commitment.

$\mathrm{H} 2$ : Interpersonal communication influences organizational commitment.

H3: Organizational culture influences Organizational Citizenship Behavior.

H4: Interpersonal communication influences Organizational Citizenship Behavior.

H5: Organizational commitment influences Organizational Citizenship Behavior.

H6: Organizational culture influences Organizational Citizenship Behavior through organizational commitment.

H7: Interpersonal communication influences Organizational Citizenship Behavior through organizational commitment.

\section{Method Research}

The research was conducted at PT. Jaktour is a Regional Owned Enterprise that is engaged in the hospitality industry in the Special Capital Region of Jakarta. The unit of analysis of this research is all employees of PT. Jaktour which covers 8 (eight) units of offices it manages. The research population used was all employees working at PT. Jaktour with a total population of 581 people. Sampling used by probability sampling technique is proportionate stratified random sampling. The number of samples is determined by using the Slovin formula with a level of error $\varepsilon=0.05$ so that a sample of 237 respondents was obtained. The research method uses quantitative methods. Data collection is done through questionnaires. The statement in the questionnaire was measured using a Likert scale. The data that has been analyzed is intended to obtain information and conclusions can be drawn right and correctly. Thus it is necessary to analyze the data in accordance with the objectives of the research that has been formulated, as well as to test the hypotheses that have been set. In the data quality test is to test the validity of the instrument. Continued to test the level of reliability of the data using the Cronbach Alpha indicator. In this 
study, the collected data was analyzed using SEM (Structural Equation Modeling) using AMOS software which was previously tested by the model.

\section{Result and Discustion}

The testing of the validity, reliability and normality, the next step is testing the model hypothesis with the SEM model. The test was conducted to find out the models obtained fulfilling the goodness of fit measures including chi-square statistics, comparative fit index (CFI), normal chi-square (CMIN / DF), and the root mean square error of approximation (RMSEA). Based on the initial model it is still necessary to make modifications to the model to improve the Goodness of Fit index; following the results.

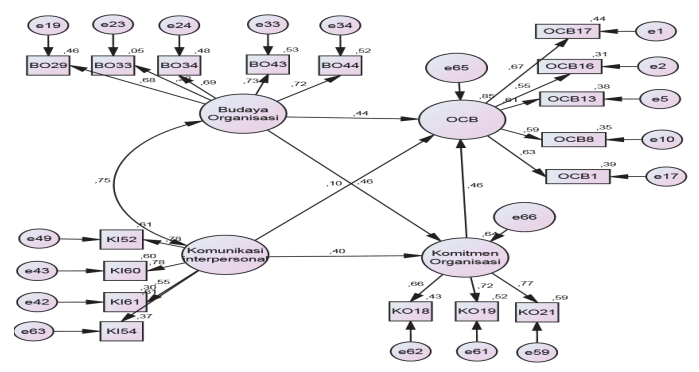

Fig.1. Structure Equation Modification Model

Based on the output diagram, it can be seen the influence of organizational culture and communication on organizational citizenship behavior (OCB) with organizational commitment as a mediating variable.

Tabel 1

Regression Weight Structural Equation Modeling

\begin{tabular}{|c|c|c|c|c|c|c|}
\hline \multicolumn{3}{|c|}{ Variabel } & Estimate & S.E. & C.R. & $\mathrm{P}$ \\
\hline organizational commitment & $\leftarrow$ & Organizational culture & 0.430 & 0.121 & 3.550 & $* * *$ \\
\hline Organizational commitment & $\leftarrow$ & Interpersonal communication & 0.354 & 0.111 & 3.199 & 0.001 \\
\hline OCB & $\leftarrow$ & Organizational culture & 0.399 & 0.119 & 3.368 & $* * *$ \\
\hline OCB & $\leftarrow$ & Interpersonal communication & 0.084 & 0.101 & 0.830 & 0.406 \\
\hline $\mathrm{OCB}$ & $\leftarrow$ & organizational commitment & 0.448 & 0.129 & 3.480 & $* * *$ \\
\hline
\end{tabular}

Source: primary data analysis (2018)

The results of the data analysis, it can be described as follows:

The first hypothesis (H1): There is a direct influence of organizational culture on organizational commitment. Organizational culture has a positive and significant effect on employee organizational commitment at PT. Jaktour. This is indicated by the $\mathrm{P}$ value of $0.000(0 \%)$ which is below the alpha of 5\% (0.05). Thus the H1 hypothesis is proven in this analysis. This is in accordance with the theory put forward by Kreitner and Kinicki (2014), who explain that organizational culture can be a driver of worker behavior, organizational performance and effectiveness. This is also in line with the theory of Robbins and Judge (2015), which explains that organizational culture has a vital role in the organization since it is the habits that occur in the organizational hierarchy that represents behavioral norms that are followed by members of the organization, strong organizational culture indicates the high employee loyalty and commitment to the organization, so that they can direct organizational citizenship behavior from employees. According to Tika (2014), the main function of organizational culture is to shape employee behavior. Wahab's opinion (2018), organizational culture is a pattern of organizational beliefs and values that are understood, imbued and practiced by organizations, so that the pattern gives its own meaning and becomes the basis for the rules of behavior in the organization. Therefore, organizational culture is used as a controller and direction in shaping human attitudes and behaviors that exist within the organization. Implementation of organizational culture at PT. Jaktour runs so well that OCB employees in the PT. Jaktour also increased. The results of this study are also in line with the studies conducted by Oemar \& Yohanes (2013); Rini et al., (2013); Dewangga et al., (2016), who concluded that organizational culture has an effect on OCB. The fourth hypothesis (H4): The direct influence of interpersonal communication on organizational citizenship behavior (OCB). Interpersonal communication does not affect OCB employees of PT. Jaktour. This is indicated by the $\mathrm{P}$ value of $0.406(40 \%)$ which is above the alpha of 5\% (0.05). Thus the hypothesis H4 is not proven in this analysis. This is not in line with the theory put forward by Luthans and Fred (2011), communication is a basic method that influences behavior so that the expected effect is achieved. Although various attempts at communication have been carried out by PT. Jaktour; but still most employees do not care which results in lower citizenship behavior. Similarly, the theory put forward by Robbins \& Judge (2015), is not in line that communication acts to control employee behavior. Similarly, when viewed from the conclusions of the results of the Herfina et al. (2015) study, it also does not support that the conclusions of 
interpersonal communication research have a positive and significant effect on OCB. The fifth hypothesis (H5): The direct influence of organizational commitment to organizational citizenship behavior (OCB). Organizational commitment has a positive and significant effect on OCB employees of PT. Jaktour. The condition is indicated by the P value of $0,000(0 \%)$ which is below the alpha of $5 \%(0.05)$. Thus the H5 hypothesis is proven in this analysis. If organizational commitment increases, OCB employees in the PT. Jaktour also experienced an increasing trend. This is in accordance with the theory from Robbins \& Judge (2015), that OCB can arise from a variety of factors in the organization including the existence of job satisfaction from employees and high organizational commitment. When a person has a high commitment to his organization, that person will do anything to advance his company because of his belief in his organization. The opinion of Kolowsky, Caspy, Lazar \& Inkson in Sopiah (2008), the impact arising from organizational commitment is the behavior of members of organizations with higher organizational citizenship behavior. According Luthans \& Fred (2011), that employee commitment relates to other desired outcomes such as climate perceptions, warm and supportive organizations and good team members who are ready to help. The research conducted by Putrana et al., (2016), Purnami (2013), Maysarah et al., (2015), in concluding his research that organizational commitment influences OCB. The hypothesis testing of the influence of each variable, the next analysis looks at the direct and indirect effects of the previously formed model. The results of the analysis are as follows.

Table 2

Direct Effects, Indirect and Total Influences

\begin{tabular}{|c|c|c|c|}
\hline Relations between Variables & Direct Effects & Indirect Effects & Total Effect \\
\hline Organizational culture to organizational commitment & 0.456 & - & 0.456 \\
\hline Interpersonal communication to organizational commitment & 0.399 & - & 0,399 \\
\hline Organizational culture to Organizational Citizenship Behavior (OCB) & 0.438 & - & 0.438 \\
\hline Interpersonal communication to Organizational Citizenship Behavior (OCB) & 0.098 & - & 0.098 \\
\hline Organizational commitment to organizational citizenship behavior (OCB) & 0.463 & - & 0.463 \\
\hline $\begin{array}{l}\text { Organizational culture towards organizational citizenship behavior (OCB) through organizational } \\
\text { commitment }\end{array}$ & - & 0.211 & 0.211 \\
\hline $\begin{array}{l}\text { Interpersonal communication towards organizational citizenship behavior (OCB) through } \\
\text { organizational commitment }\end{array}$ & - & 0.185 & 0.185 \\
\hline
\end{tabular}

Source: primary data analysis (2018)

Table 2 shows 5 (five) direct influences and 2 (two) indirect effects in the study. The greatest direct effect is organizational culture on organizational commitment, while the smallest influence is interpersonal communication on organizational commitment. The indirect effects the greatest influence is on the influence of organizational culture on organizational citizenship behavior (OCB) through organizational commitment. The Sobel test will be conducted to ensure there are indirect effects or mediating effects of interviening variables; the results of the Sobel test are as follows.

Table 3

Sobel Test Results on the Effects of Mediation between Variables

\begin{tabular}{|c|c|c|c|}
\hline Path & $t_{\text {hitung }}$ & $\mathrm{t}_{\text {tabel }}(5 \%)$ & Keterangan \\
\hline $\begin{array}{l}\text { Organizational culture towards organizational citizenship behavior } \\
\text { (OCB) through organizational commitment }\left(\mathrm{H}_{6}\right)\end{array}$ & 2.483 & 1.965 & Significant in alpha $5 \%(0.05)$ \\
\hline $\begin{array}{l}\text { Interpersonal communication towards organizational citizenship } \\
\text { behavior }(\mathrm{OCB}) \text { through organizational commitment }\left(\mathrm{H}_{7}\right)\end{array}$ & 2.348 & 1.965 & Significant in alpha $5 \%(0.05)$ \\
\hline
\end{tabular}

Source: Data processing results (2018)

Table 3 shows on both lines or on indirect effects there are different influences. In the mediation of organizational culture on OCB through organizational commitment there was a significant effect on alpha $5 \%(0.05)$. The mediation of interpersonal communication with OCB through organizational commitment there was a significant effect on alpha $5 \%(0.05)$. Thus there is an intervining effect on both routes. The sixth hypothesis (H6): The influence of organizational culture on organizational citizenship behavior (OCB) through organizational commitment. Hypothesis testing shows positive and significant values. The Sobel test results also confirm that organizational commitment mediates between organizational culture variables towards OCB. The higher cultural values possessed and developed at PT. Jaktour and mediated by organizational commitment will increase OCB of employees who are assigned to PT. Jaktour. This is in accordance with the theory from Gordon in Sutrisno (2017), that culture functions as a social glue that helps unite the organization by providing appropriate standards for what employees must say and do. Finally, culture functions as a mechanism for making meaning and control that guides and shapes the attitudes and behavior of employees. Similarly, in accordance with the theory put forward by Robbins \& Judge (2015), that in a strong culture, the noble values of the organization will be adhered to intensively and widely disseminated. More and more members receive noble values and the greater their commitment, the culture will be stronger and the greater the influence on the behavior of members. And in accordance with research conducted by Wijaya et al., (2017), Ariani et al., (2017) and Khan et al., (2015). So it can be concluded that organizational culture influences OCB through organizational commitment. Seventh hypothesis (H7): The influence of interpersonal communication on organizational citizenship behavior (OCB) through organizational commitment. Testing the sixth and seventh hypotheses shows different significance values. The influence of interpersonal communication on organizational commitment shows a significant 5\% alpha, while interpersonal communication with OCB shows insignificant value. The influence of the mediating variable between the two variables can be confirmed from the Sobel test which shows that there are influences of mediating variables. The mediation of the variable 
organizational commitment with interpersonal communication with OCB. According to Sopiah (2008), that interpersonal communication serves to build organizational commitment by conducting broader two-way communication to build charisma, make rules that become habits that aim to influence the attitudes and behavior of organizational members. The results of this research found that the effect of interpersonal communication on its value is still needed as a vehicle for efforts to strengthen good communication at every opportunity.

\section{Conclusion}

The conclusions of the research are: (1) Organizational culture has a positive and significant effect on employee organizational commitment at PT. Jaktour. These results indicate that a good and conducive organizational culture is the commitment of employees of PT. Jaktour will increase. (2) Interpersonal communication has a positive and significant effect on employee organizational commitment at PT. Jaktour. These results indicate that good interpersonal communication then the organizational commitment of employees of PT. Jaktour will increase. (3) Organizational culture has a positive and significant effect on OCB employees of PT. Jaktour. These results indicate that a good and conducive organizational culture, the behavior of OCB employees of PT. Jakstour will increase. (4) Interpersonal communication does not affect OCB employees of PT. Jaktour. These results indicate that interpersonal communication cannot influence the OCB of employees of PT. Jaktour. (5) Organizational commitment has a positive and significant effect on OCB employees of PT. Jaktour. These results indicate that if organizational commitment increases, OCB employees of PT. Jaktour increases. (6) Organizational culture influences OCB through the organizational commitment of PT. Jaktour. These results indicate that organizational commitment mediates the relationship between organizational culture and OCB. (7) Interpersonal communication has an effect on OCB through organizational commitment at PT. Jaktour. These results indicate that organizational commitment mediates the relationship between interpersonal communication and OCB. The findings of the research show that the influence of interpersonal communication is still needed as a vehicle for efforts to strengthen good communication at every opportunity. The implications of the results of this study refer to building culture and communication in the field of hotel accommodation at the metropolitan level capable of reflecting national culture as a mirror of Indonesia rich in regional culture that is diverse in ethnicity and makes it unique for tourists. In the future, researchers can look deeper into the unique and interesting potential of regional culture to be explored and further developed.

\section{References}

Adianita, A. S., Mujanah, S., \& Candraningrat, C. (2017). Kompetensi Karyawan, Emotional Quotient dan Self Efficacy pengaruhnya Terhadap Organizational Citizenship Behavior dan Kinerja Karyawan Pada Indomobil Grup di Surabaya. Jurnal Riset Ekonomi dan Manajemen, 17(1), 199-212.

Anam, C. (2017). Pengaruh Komitmen Organisasi, Komunikasi Interpersonal dan Kepuasan Kerja Terhadap Organizational Citizenship Behavior Pada Anggota Kepolisian Resort Jombang. MARGIN ECO, 1(1), 17-39.

Ariani., Nina \& Yuniawan. (2017). Analisis pengaruh budaya organisasi dan dukungan organisasi terhadap organizational citizenship behavior dengan komitmen organisasi sebagai variabel intervening. Diponegoro Journal of Management, 6(4), 1-13.

Badawy, T. A., Kamel, M. M., \& Magdy, M. M. (2016). Exploring the relationship between organizational culture, job satisfaction and organizational citizenship behavior. International Journal of Human Resource Studies, 6(4), 20.

Banhwa, P. F., Chipunza, C., \& Chamisa, S. F. (2014). The influence of organisational employee engagement strategies on organisational citizenship behaviour within retail banking. A case of amatole district municipality. Mediterranean Journal of Social Sciences, 5(6), 53.

Cangara, H. (2000). Pengantar Ilmu Komunikasi. Jakarta: PT. RajaGrafindo Persada.

Colquitt, Lepine \& Wesson. (2019) .Organizational Behavior Improving Performance and Commitment in the Workplace, 6th ed. US: McGRAW-Hill Irwin.

Deery, S., Rayton, B., Walsh, J., \& Kinnie, N. (2016). The costs of exhibiting organizational citizenship behavior. Human Resource Management, 56(6), 1039-1049. doi:10.1002/hrm.21815

Dessler, G. (2008). Human Resources Management. New Jersey: Prentice Hall. Inc.

DeVito, J. (2004). The Interpersonal Communication Book, $10^{\text {th }}$ ed. Boston: Pearson-Allyn \& Bacon

Dewanggana, B. D., Paramita, P. D., \& Haryono, A. T. (2016). Pengaruh Komitmen Organisasi, Kepuasan Kerja, Budaya Organisasi terhadap Organizational Citizenship Behavior (OCB) yang Berdampak pada Prestasi Kerja Karyawan (Studi pada PT. PLN App Semarang). Journal of Management, 2(2).

Dewi, I. G. A. K. R., \& Surya, I. B. K. (2017). Pengaruh Budaya Organisasi Terhadap Komitmen Organisasional Dan Organizational Silence Pada Pt. Pln (Persero) Rayon Denpasar. E-Jurnal Manajemen, 6(1), 289-316.

Felicia, A. (2017). Pengaruh komitmen organisasional terhadap organizational citizenship behavior di Hotel Gunawangsa Manyar Surabaya. Jurnal Hospitality dan Manajemen Jasa, 5(2), 368-370.

Herfina., A., \& Rubini. (2015). The relationship among trasnformational leadership, work satisfaction and interpersonal communication to teachers' organziational citizenship behavior. International Journal of Managerial Studies and Research (IJMSR), 3(4), 11-16.

Indrawijaya, A. I. (2010). Teori, Perilaku, dan Budaya Organisasi. Bandung: Refika Aditama.

Sh, K., \& Sh, P. (2014). The relationship between quality of work life, job stress, job satisfaction and citizenship behavior in oshnaviyeh hospital's staff. Journal of Patient Safety \& Quality Improvement, 2(2), 77-81.

Khan., Kadar., Zabid \& Rashid. (2015). The mediating effect of organization commitment in the organization culture, leadership and organization justice relationship with organization citizenship behavior: A study of academics in private higher learning institutions in Malaysia. International Journal of Recent Advances in Organizational Behavior and Decision Sciences (IJRAOB), 1(2), 335-359.

Kreitner, R., \& Kinicki, A. (2014). Organizational Behavior. $9^{\text {th }}$ ed. Boston: McGraw Hill Education. 
Lee, K., \& Allen, J. (2002). Organizational citizenship behavior and workplace deviance: the role of affect and cognition. Journal of Applied Psychology, 87, 131-142.

Lindawati \& Rita, Dwi. (2014). Pengaruh komunikasi interpersonal dan stress kerja terhadap komitmen organisasi pegawai pusdiklat Bea dan Cukai. Jurnal Manajemen Pendidikan, 5(2), 878-887.

Luthans \& Fred. (2011). Organizational Behavior: An Evidence-Based Approach. New York: McGraw-Hill Irwin.

Mahasneh, M. A. (2015). The impact of organizational citizenship behavior on job performance at greater amman municipality. European Journal of Business and Management, 7(36).

Maysarah., Sari \& Rahardjo. (2015). Analisis pengaruh budaya organisasi, keadilan organisasi dan komitmen organisasional terhadap organizational citizenship behavior: Studi pada PT. Kereta Api Indonesia (Persero) daerah operasi 4 Semarang. Diponegoro Journal of Management, 4(4), 1-14.

Mondy \& Noe. (2005). Human Resource Management. Published by Prentice Hall PTR.

Moorhead, G., \& Griffin, R. W. (2013). Organizational Behavior. Human Resource Management and Organization. Jakarta: Penerbit Salemba Empat.

Mustikasari \& Anis. (2014). Pengaruh budaya organisasi terhadap komitmen pegawai dinas pendidikan. Manajemen Pendidikan, 24(4), 341-349.

Newstrom, J. W., \& Davis, K. (2008). Organizational Behavior, Human Behavior at Work” Tent Edition, New York: McGraw-Hill International Edition.

Oemar \& Yohanes. (2013). Pengaruh budaya organisasi, kemampuan kerja dan komitmen organisasi terhadap organizational citizenship behavior (OCB) pegawai pada BAPEDDA Kota Pekanbaru. Jurnal Aplikasi Manajemen, 3(1), 65-76.

Organ, D W. (2015). Organizational Citizenship Behavior. In International Encyclopedia of the Social \& Behavioral Sciences, 2nd ed., 317-321.

Organ, D. W., Podsakoff, P. M. \& MacKenzie, S. B. (2008). Organizational Citizenship Behavior: Its Nature, Antecedents and Consequences. California: Sage Publication.

Podsakoff, P. M., MacKenzie, S. B., Paine, J. B., \& Bachrach, D. G. (2000). Organizational citizenship behaviors: A critical review of the theoretical and empirical literature and suggestions for future research. Journal of Management, $26(3), 513-563$.

Purnami, R. S. (2013). Pengaruh kepuasan kerja dan komitmen organisasional terhadap perilaku kewargaan organisasional serta implikasinya terhadap kinerja pegawai administrasi politeknik komputer niaga LPKIA Bandung. Jurnal Ilmu Manajemen \& Bisnis, 4(2), Maret 1-15.

Putra, M. G. A. M., \& Putra, M. S. (2018). Pengaruh kepuasan kerja dan komitmen organisasi terhadap turnover intention agen asuransi PT. Prudential indonesia. Matrik: Jurnal Manajemen, Strategi Bisnis dan Kewirausahaan.

Putrana., Y.., Fathoni \& Warso. (2016). Pengaruh kepuasan kerja dan komitmen organisasi terhadap organizational citizenship behavior dalam meningkatkan kinerja karyawan pada PT. Gelora Persada Mediatama Semarang. Journal of Management, 2(2).

Rashid, M. Z. A., Sambasivan, M., \& Johari, J. (2003). Pengaruh budaya perusahaan dan komitmen organisasi terhadap kinerja. Journal of Management Development, 22, 708-28.

Robbins, S. P., \& Koulter, M. (2016). Management, 13th ed. New Jersey: Pearson Education.

Robbins, S. P., \& Judge, T. A. (2015). Organizational Behavior, 16th ed., New Jersey: Pearson Education.

Schermerhorn, J. R., Hunt, J. G., \& Osborn, R. N. (2011). Organizational Behavior. New York, NY: Wiley.

Sharma, J., \& Dhar, R. L. (2016). Factors influencing job performance of nursing staff: Mediating role of affective commitment. Personnel Review, 45(1), 161-182.

Siburian., T. A. (2013).The Effect of Interpersonal Communication, Organizational Culture, Job Satisfaction and Achievement Motivation to Organizational Commitment of State High School Teacher in the District Humbang Hasundutan, North Sumatera,.International Journal of Humanities and Social Science, 3(12), 247-264.

Sopiah. (2008). Perilaku Organisasional. Yogyakarta: C.V Andi Offset.

Subejo., Troena., Thoyib \& Aisjah. (2013). The effect of organizational commitment and organization identity strength to citizenship behaviour (OCB) impact on fire departmentand disaster employee performance in Jakarta Indonesia. IOSR Journal of Business and Management, 10(3), 30-36.

Suranto, A.W. (2011). Kmunikasi Personal. Yogyakarta: Graha Ilmu.

Sutrisno, E. (2017). Manajemen Sumber Daya Manusia. Jakarta: Kencana.

Thoha,Miftah. (2016). Perilaku organisasi.Jakarta: Rajawali.

Tika. (2014). Budaya Organisasi dan Peningkatan Kinerja Perusahaan. Jakarta: PT. Bumi Aksara.

Usmany, Tiara Putri., Hamid, Djamur \& Utami, Hamidah Nayati. (2016). Pengaruh budaya organisasi terhadap komitmen organisasional dan kinerja karyawan. Jurnal Administrasi Bisnis (JAB), 37(2), 38-44.

Wahab, A. (2018). Anatomi Organisasi dan Kepemimpinan Pendidikan: Telaah terhadap Organisasi dan Pengelolaan Organisasi Pendidikan. Bandung: Alfabeta.

Wijaya, Nina Ariani \& Ahyar Yuniawan. (2017). Analisis pengaruh budaya organisasi dan dukungan organisasi terhadap organizational citizenship behavior dengan komitmen organisasi sebagai variabel intervening: studi pada karyawan bagian antaran PT. Pos Indonesia Processing Center Semarang. Diponegoro Journal of Management, 6(4), 1-13.

Winata, G. (2017). Refleksi Keterampilan Manajerial, Komunikasi Interpersonal dan Budaya Mutu Berfokus pada Perilaku Anggota Organisasi (Organizational Citizenship Behavior). Inovasi Pembangunan: Jurnal Kelitbangan, 5(2), 121-136.

Zanuchi., Jaja S A \& Okhuha O. (2014). An Empirical study on relationship between emplyoee engagement and organizational citizenship behaviorin marritime firms, onne, Nigeria. International Journal of Advanced Academic Research | Social \& Management Sciences, $3(2), 16-32$.

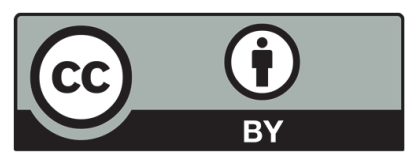

(C) 2020 by the authors; licensee Growing Science, Canada. This is an open access article distributed under the terms and conditions of the Creative Commons Attribution (CC-BY) license (http://creativecommons.org/licenses/by/4.0/). 